\title{
ICELANDIC AS A SECOND LANGUAGE: UNIVERSITY STUDENTS' EXPERIENCES
}

The aim of this paper is to present and analyze how university students experience teaching methods of Icelandic as a second language and communication with teachers during the learning process. The theoretical framework includes multicultural education theory and second language teaching and learning theories. The findings are based on qualitative interviews with twelve students who study Icelandic as a second language at the University of Iceland. The analysis of the interviews revealed that the participants were generally satisfied with the learning environment and had positive experiences of communication with the majority of the teachers. Nevertheless, the participants described themselves as being rather passive recipients of knowledge in the courses where explicit teaching of grammar was applied, and lacking active participation in the learning process. Additionally, the participants encountered several challenges during the learning process such as issues related to task-based and group assignments and, in some cases, teachers lacked understanding of different students' needs, such as that of providing extra learning materials.

Keywords: higher education, second language, teaching methods, qualitative research, Icelandic

\section{INTRODUCTION}

Icelandic language courses for university students have been available in the School of Humanities at the University of Iceland since 1954 (Hjartardóttir, 2000). Both teaching methods and course materials have changed significantly since that time. Nowadays, the University of Iceland offers a variety of courses in Icelandic as a second language. Two different programs have been developed within the School of Humanities; the Icelandic as a Second Language Practical Diploma (60 ECTS) and the Icelandic as a Second Language BA Program (180 ECTS). These two programs have some important differences. The Practical Diploma program is designed for beginners and exchange students who take an interest in learning Icelandic. The Icelandic as a Second Language BA Program is a full degree program designed for students who have an academic interest in Icelandic language and culture (University of Iceland, n.d.-b). 
The full BA degree program includes various courses that focus on developing different language skills. In courses such as Grammar and Syntax, explicit teaching methods are used, and the main focus is on grammar and linguistic competence in Icelandic (University of Iceland, 2017). On the other hand, courses such as Conversational Practice focus on advancing students' communicative competence, and implicit teaching methods are usually applied (University of Iceland, 2017). The terms explicit teaching and implicit teaching are antonyms, where the former term implies intentional teaching approaches, during which students are instructed to learn language rules and practice them through pattern drills and similar exercises (N. C. Ellis, 2015). The term implicit teaching refers to teaching approaches based on the notion that students should acquire language skills, including linguistic competence, naturally through different classroom activities, such as group work and class discussion (N. C. Ellis, 2015).

Despite the long tradition of teaching Icelandic as a second language at the University of Iceland, little knowledge exists on university students' experiences of the teaching methods. Hence, it is highly relevant to provide insight into students' experiences of learning Icelandic as a second language and to highlight the main challenges and obstacles that could impact their academic performance.

The main focus of this paper is to explore how university students experience the teaching methods of Icelandic as a second language courses offered in the two different programs at the University of Iceland. Furthermore, the paper aims to present and analyze students' experiences of communication with teachers during the learning process. It is important to highlight that the goal of this paper is not to compare the Icelandic as a Second Language Practical Diploma Program (60 ECTS) with the Icelandic as a Second Language BA Program (180 ECTS).

The statistics available on the University of Iceland's webpage suggest that there is significant dropout from the Icelandic as a Second Language programs (University of Iceland, n.d.-a, n.d.-c). From 2009-2018, there was an average of 83 newly registered students in the BA program, while an average of only 16 students graduated with the BA degree during the same time frame (University of Iceland, n.d.-a, n.d.-c). When it comes to the Practical Diploma, from 2009-2018, the average number of newly registered students was 82, while on average 32 students graduated from the Practical Diploma program during the same period (University of Iceland, n.d.-a, n.d.-c). This statistical data provides a rough estimate of the dropout rate. In order to reveal the exact numbers, a separate quantitative study should be conducted using more detailed data from the office of the registrar.

The paper is based on results from twelve individual, in-depth interviews with university students who have taken at least three different courses in Icelandic as a second language. The main research questions are presented below:

- What are the participants' experiences of communication with teachers during the learning process?

- What are the participants' reactions to and reflections on implicit teaching methods that focus on developing communicative skills?

- What are the participants' experiences of courses where explicit teaching of grammar is applied? 
This paper is derived from the qualitative research project Educational Aspirations, Opportunities and Challenges for Immigrants in University Education in Iceland conducted from 2016 to 2018. The project was funded by the Icelandic Centre for Research (Rannís).

The paper includes five sections and an abstract. The next section presents the theoretical framework of the study. The theoretical framework mainly focuses on multicultural education theory, specifically culturally responsive teaching and second-language teaching theories. The third section covers research design and methods of data collection. The fourth section combines presentation and discussion of the findings. The fifth section is a conclusion comprising several final remarks.

\section{THEORETICAL FRAMEWORK}

According to previous research (Erisman \& Looney, 2007; Sinacore \& Lerner, 2013), limited language skills, lack of support and insufficient language teaching for immigrant students can have a serious impact on the students' learning outcomes and sense of belonging in the learning environment. Furthermore, knowledge of the dominant cultures' languages is considered to be an important element in the integration process as language is inseparable from culture (Erisman \& Looney, 2007; Sinacore \& Lerner, 2013). In contemporary education, it is highly relevant to implement teaching and assessment methods designed with equity in mind because they provide equal learning opportunities to all students regardless of nationality, race or any other status.

The essence of multicultural education is to create an empowering school environment where all students, regardless of their origin or social status, have equal access to education and are treated with respect by peers and teachers (Banks \& Banks, 2010; Nieto, 2010). Culturally responsive teaching (Gay, 2018; Villegas \& Lucas, 2002) is a learner-centered approach to teaching within multicultural education theory. Culturally responsive teachers try to understand their own cultural identity and their students' cultural identities through dialogue in the classroom and they allow every student to bring his or her own knowledge, talents, and experiences to invest in the learning process (Gay, 2018). Furthermore, multicultural education theory and previous research emphasize the importance of applying diverse and unbiased assessment methods in culturally diverse classrooms (Montenegro \& Jankowski, 2017; Nicol \& Macfarlane-Dick, 2006; Padilla \& Borsato, 2008; Slee, 2010). According to Padilla and Borsato (2008), high-stakes examinations, such as final exams, are not always fair towards students from culturally diverse backgrounds, including immigrants. Culturally responsive assessment does not measure students' achievement based on standardized criteria only (Padilla \& Borsato, 2008; Slee, 2010). Teachers are encouraged to take students' cultures, previous experiences and individual learning styles into consideration and to assess learning by prioritizing diverse low-stakes tests and assignments applied evenly throughout the learning process (Nicol \& Macfarlane-Dick, 2006; Padilla \& Borsato, 2008).

Culturally responsive teaching may be related to constructivist theory in the way that it highlights educational shifts from mere knowledge acquisition to empowering experiences of knowledge exchange (Banks \& Banks, 2010; Gay, 2018). Constructivist theory 
emphasizes discovery as an essential element of the learning process and learning is considered to be active knowledge construction performed by the students themselves (Birenbaum, 2003; Cornelius-White, 2007). The role of students is transformed from being passive recipients of knowledge to becoming active participants in the learning process (Cornelius-White, 2007; Schiller, 2009). Students' active participation is an essential element in the culturally responsive approach to teaching (Gay, 2018; Villegas \& Lucas, 2002). Classroom activities such as discussions and group work are recommended in learning environments with diverse student populations because such activities motivate students to actively participate in the learning process (De Vita, 2005; Sweeney, Weaven, \& Herington, 2008). According to the results of previous research, multicultural group work has a positive effect on students' performance and their integration into the learning environment (De Vita, 2005; Popov et al., 2012; Sweeney et al., 2008). These activities are also useful in language learning environments, as they activate students, encourage them to use the target language during discussions and group work and, thereby, improve their communicative language skills (Oroujlou \& Vahedi, 2011; Pedersen, 2007; Wesche \& Skehan, 2002). When it comes to second language teaching, it is as important to work on developing students' knowledge of the language as it is to teach the students to use the language actively in everyday life.

Focus-on-forms is an explicit teaching approach, where the syllabus includes a predetermined list of linguistic forms that students are supposed to practice through a set of exercises (Long, 2011). This approach has been widespread within the field of second language teaching. The early theorists of explicit teaching methods of grammar concluded that intensive exercises of grammar rules are an essential element in the language acquisition process (Harmer, 1987; Lado, 1964). Student involvement in the learning process is very limited. Thus, this approach is considered to be less motivating and not learnercentered (N. C. Ellis, 2015; Long, 2011). Focus-on-forms is usually opposed to the teaching approach called focus-on-form, which claims that a better learning outcome could be achieved by occasionally drawing students' attention to linguistic elements, including morphology and syntax during lessons that are primarily focused on communication or meaning (R. Ellis, 2012; Long, 2011).

Focus-on-form is considered to be a learner-centered approach which activates students and has a positive effect on their involvement in the learning process (R. Ellis, 2009,2012 ). Focus-on-form combines elements of explicit language teaching and implicit language teaching (R. Ellis, 2012; Loewen, 2005). Theorists argue that traditional grammar teaching has different negative side-effects that can be avoided by rejecting explicit teaching of grammar rules based on pattern drills and by incorporating grammar teaching into communicative activities that motivate students (R. Ellis, 2012; Long, 2011). Focus-on-form is divided into two types: incidental focus-on-form and planned focus-onform, where the planned focus-on-form implicates the use of predetermined tasks with a specific focus on linguistic elements (R. Ellis, 2012). On the other hand, the distinctive feature of incidental focus-on-form is that teaching of grammar is applied "spontaneously without prior planning in meaning-focused interaction" (Loewen, 2005, p. 361). Incidental focus-on-form is supported by Swain's (1993) output hypothesis, which claims that second language acquisition is more effective when students become aware of their 
knowledge gaps and learn something new about the target language by making an effort to modify their output (Loewen, 2005; Swain, 1993; Swain \& Lapkin, 1995). Both Loewen (2005) and Swain $(1993,2005)$ emphasize that, in order to develop students' language skills, some explicit teaching methods need to be applied especially when students are graded in accordance with their academic performance and improvement.

In contrast to explicit language teaching methods, implicit or usage-based teaching methods prioritize meaning instead of forms and use communication as a tool to acquire language skills (N. C. Ellis, 2015). Early in the 1980s, Krashen pointed out that the acquisition of a second language should take place in a stress-free environment without an extensive focus on the linguistic elements (Krashen, 1985). This natural learning environment could be achieved by applying implicit teaching methods, where communication is an important element of the learning process. Communicative teaching methods have some essential characteristics, such as teachers using authentic texts and applying learner-centered approaches that motivate students (Wesche \& Skehan, 2002). This corresponds to culturally responsive teaching methods, where special attention is also given to communication during the learning process (Gay, 2018). Furthermore, students are encouraged to share their knowledge with peers while resolving task-based communicative assignments provided by teachers (Richards, 2006; Wesche \& Skehan, 2002). By using communicative language teaching methods, teachers not only develop students' language skills but also create social interaction in the classroom (Pedersen, 2007; Richards, 2006). Different classroom activities are suggested, such as group work, interviews, opinion sharing, and role play.

The task-based teaching approach claims to develop all language skills, including listening, reading, speaking, and writing, as well as creating a productive learning environment by motivating students to participate in the learning process (R. Ellis, 2009; Pedersen, 2007). However, the theorists strongly suggest that teachers should apply task-based assignments carefully and take students' existing knowledge and language skills into consideration (R. Ellis, 2009; Richards, 2006). The key characteristics of a task are introduced by Richards (2006), who claims that a task requires students to use their existing language resources. Tasks focus on meaning and have "an outcome which is not simply linked to learning language, though language acquisition may occur as the learner carries out the task" (Richards, 2006, p. 31). While no task fits all classrooms, every task must be tailored to a particular group of students in order to achieve good results (R. Ellis, 2009; Swan, 2005).

Theodórsdóttir and Friðriksdóttir (2013) explored how students of Icelandic as a second language experienced a task-based assignment called Íslenskuporpið (The Icelandic Village). Their theoretical framework was based on a paper by Wagner (2004), who suggested that adding a social dimension into task-based instruction by sending students out of the classroom and encouraging them to use their language resources could have benefits and develop students' communicative competences. The task, Íslenskuporpið, aimed to promote daily interaction in Icelandic and to improve students' language skills by speaking Icelandic to Icelanders, recording and analyzing the conversations. The findings presented by Theodórsdóttir and Friðriksdóttir (2013) were positive and they reported students' satisfaction with the task. 
Different levels of curiosity and motivation amongst students could be among the challenges that teachers might experience during the teaching process (Karge, Phillips, Jessee, \& McCabe, 2011; Norton \& Toohey, 2011). However, Norton and Toohey (2011), in their work on identity and language learning, point out that motivation and investment in the learning process are two different things. A highly motivated student could have little investment in the learning process, which can be explained by the student's lack of a sense of belonging in the classroom or negative attitudes from teachers or peers. The role of the teacher is to be observant of tendencies in the classroom and provide better support for students whose investment is relatively low as compared to other students (Norton \& Toohey, 2011).

Both explicit and implicit teaching methods have their pros and cons. Explicit teaching methods are criticized for being less relevant and having little practical value (Long, 2011; Norris, 2011), while implicit teaching lacks advanced insight into linguistic elements of the language which could help students to further develop their language skills (N. C. Ellis, 2015). According to previous research, it is reasonable to incorporate the teaching of linguistic elements into communicative language teaching by applying incidental focus-on-form (Loewen, 2005). However, this teaching approach must be carefully tailored to the particular students in order to achieve better learning outcomes (R. Ellis, 2009; Swan, 2005).

The theoretical framework creates a base for the presented study. The theories and earlier research will be used to discuss the findings from different perspectives. In the next section, the research design and methods of data collection are presented.

\section{METHOD}

The project Educational Aspirations, Opportunities and Challenges for Immigrants in University Education in Iceland (2016-2018) is a qualitative study based on interviews with 41 university students, who are first-generation immigrants in Iceland. In Iceland, the term immigrant is applied to "a person born abroad with two foreign-born parents and four foreign-born grandparents" (Statistics Iceland, 2016). Only those immigrant students who had studied at undergraduate level for at least one year were recruited to participate in the study. The additional requirement was that the participants were not exchange-students. Information on some participants was obtained from the office of the registrar, while the majority were recruited by using a snowball sampling method (Flick, 2009).

As this paper focuses on students' experiences of teaching methods for Icelandic as a second language, the findings are based on individual interviews with those participants who have taken at least three courses in Icelandic as a second language at the University of Iceland (from the Icelandic as a Second Language Practical Diploma Program and/or Icelandic as a Second Language BA Program). Twelve participants out of the 41 in the larger study met the selection criterion. These participants come from eight different countries in Europe, Asia and North America and have been living in Iceland from two up to twelve years. Six out of twelve participants have been registered students in the 
Icelandic as a Second Language BA Program, and as of today, one of them has graduated with the BA degree in Icelandic, two have changed their major and three have quit their studies at the University of Iceland. Three participants have been registered students at the Icelandic as a Second Language Practical Diploma Program, and as of today, two have graduated with the diploma and one has quit. Three participants took the Icelandic language courses as elective courses; that is, they did not aim to receive a degree in Icelandic and only wished to improve their language skills.

The participants were advised about the project and informed consent was obtained from all participants before the interviews started. The participants' identity and contact information is not revealed, and the study is in compliance with the privacy requirements in Icelandic law about data protection.

Data was collected through qualitative, individual, semi-structured, in-depth interviews (Brinkmann \& Kvale, 2015; Flick, 2009). All interviews were conducted in Icelandic and/or English, audio-recorded, and later transcribed verbatim. During the interviews, the students were asked to share their experiences of the learning environment, the teaching methods and their communication with teachers as well as to share their perspectives on group work and assessment methods. Additionally, several background questions were included in the interview guide. The questions relating to the main goals of this paper are presented below:

- What can you tell us about your experiences of communication with teachers?

- What teaching methods did the teachers apply?

- What do you think about these teaching methods?

- What is your experience of group work?

- What are your experiences of communication in the groups?

- What language did you use during the group work?

- What are your experiences of the assessment methods?

The interviews were analyzed using the thematic analysis approach, and the analysis took place concurrently throughout the research period (Creswell, 2008). Atlas.ti analytical software was used to code the interviews and create categories and themes. The raw data was coded using the complete coding approach (Braun \& Clarke, 2013), later the codes were organized into categories, which subsequently were developed into the three themes presented in the finding and discussion section.

\section{FINDINGS AND DISCUSSION}

The findings are divided into three sections representing the three main themes derived from the interviews. In the first section, the participants' experiences of communication with the teachers during the learning process are presented and analyzed. The second section reveals the participants' reactions to, and reflections on, implicit teaching methods focusing on developing communicative skills. Additionally, the second section includes the participants' perspectives on group work and the task-based assignment Íslenskuporpið. Finally, the third section presents the participants' experiences of courses 
where explicit teaching of grammar is applied, emphasizing the participants' perspectives on workload and assessment in those courses.

In this chapter, quotations from interviews conducted in English are presented in their original form according to interview transcriptions. Quotations from interviews conducted in Icelandic have been translated from Icelandic into English by the authors, who tried to provide as accurate a translation as possible. The analysis is solely based on the participants' interviews; that is, their memories and experiences of the teaching methods. The researchers realize that there could be inconsistencies and/or contradictions between the participants' answers and official syllabi in the courses discussed.

\section{Communication with teachers during the learning process}

The participants highlighted that the teachers' role is not solely to transmit knowledge and assess students' academic performance but also to be observant and caring for the students. Previous studies emphasized the importance of creating a positive learning environment that could have a strong impact on students' level of investment in their education (Norton \& Toohey, 2011). Generally, the participants were satisfied with their teachers and they emphasized the importance of being able to communicate with them in an informal way. Three participants said, "[t]he teachers are very accessible, and the classes are interesting", "[Translated from Icelandic] I find the teachers really, really approachable and they are interested in what they are doing", "[t]he teachers are always there for you. You know it is like a sharing process, very personal communication". These responses indicated that in many cases teachers were accessible and caring for their students. This contributed to the participants' positive experiences of the learning process and generally motivated them. According to multicultural education theory, communication with teachers is important in a multicultural classroom where the teacher should ensure that all students feel valued and participate equally in the learning process (Gay, 2018; Nieto, 2010).

The participants were not satisfied with those teachers who failed to create connections with their students and ignored suggestions coming from the classroom. During the analytical process, a pattern was discovered in several participants' comments on one of the core courses in the Icelandic as a Second Language BA Program. The participants encountered problems when requesting extra learning materials and educational support:

The teacher was always like rushing us. If you didn't understand anything, you just had to deal with it. And when I once had an interview with the teacher and [the teacher] was like "Okay I'll give you three months. If you can't do it, I will just put you in practical diploma, because you are just lower than the whole class" and I was just like ... Oh! Ok! But it wasn't my question.

Researcher: What was the question?

Like, do you have any advice on how I could just improve myself like do you have any books, anything. But it was just like "No, we have plenty of material already just deal with it". (Student in the Icelandic as a Second Language BA Program) 
The above example reveals the participant's negative experience caused by the teacher's lack of understanding of the student's needs. The teacher refused to provide additional learning material that would suit this particular student and help him to improve. Instead of offering educational support, the teacher chose to threaten the student with expulsion from the BA program. While the participant's negative attitudes may be understandable, one must take into consideration the specifics of this particular course which is one of the core courses on the Icelandic as a Second Language BA Program.

As further explained by the participants, this course had a fixed syllabus and a relatively large number of students. These could potentially be the reasons why the teacher refused to alter the syllabus or provide personal support. Nevertheless, earlier research and multicultural education theory emphasize the notion that teachers should be open to suggestions coming from students, value every student's opinion and try to provide personal support to the students (Banks \& Banks, 2010; Gay, 2018; Nieto, 2010). This has a positive effect on students' sense of belonging and motivates them. Dialogue and positive connection between students and teachers is especially important in the language learning environment, where the main goal of the education process is to teach students to communicate in a second language, which often requires active communication in the classroom.

\section{Implicit language teaching: The emphasis on active participation and communication}

The Icelandic as a Second Language BA Program includes two Conversational Practice courses where the main focus is on developing students' communicative skills (University of Iceland, 2017). The participants who took those courses generally expressed positive attitudes towards communicative teaching methods applied in the classroom. They reported that the teachers encouraged every student to participate in classroom discussions and tried to make the learning process dynamic and interesting. One of the students, who took the same course twice with a one-year pause between, commented on the changed teaching methods applied by the teachers:

[Translated from Icelandic] The course has changed a lot. I can say it is better now. We speak more. We spoke maybe just five minutes last year. Maybe not five minutes, but we spoke very little. Now in the Conversational Practice, which is once a week, we are just speaking together for one and half hours. There are discussions. (Student in the Icelandic as a Second Language BA Program)

In the same interview, the participant explained that the teacher played the role of facilitator. The teacher generated topics and encouraged the students to discuss them in Icelandic. The teacher offered assistance when the students had questions, both relating to the linguistic elements of Icelandic and to the discussion topics. This approach corresponds to the principle of incidental focus-on-form, where the teacher focuses on the linguistic elements and explains them when the issues naturally appear during lessons mainly focused on communication (Loewen, 2005). Several other participants of the study also gave positive feedback about the same course and wished that there were more such courses. 
Previous research emphasizes that encouraging students to use the target language as much as possible during classroom activities is an important principle for teachers who are implementing communicative teaching methods (Richards, 2006; Wesche \& Skehan, 2002). However, one student in the Icelandic as a Second Language BA Program commented that the teacher was not always aware of one particular problem during the classroom activities. The student pointed out that sometimes students switched to English during the discussions. "[Translated from Icelandic] I tried to speak Icelandic, but there were many who switched to English. You know, if there is a group of native English speakers, they immediately start speaking English".

The participants who were enrolled in the Practical Diploma Program specifically mentioned a communicative task-based assignment called Íslenskuporpið. According to the task requirements, the students had to work in pairs to practice Icelandic in a natural environment; they had, for example, to go together to a coffee shop or a bookshop and order a coffee or ask for assistance in Icelandic. They also had to audio-record themselves speaking Icelandic with a shop assistant and then analyze the conversation together. A pattern was discovered in the participants' answers. Their experiences were ambivalent in that they clearly understood the benefits of the idea behind the task but the experiences of doing the task were mostly negative. The participants felt they were poorly prepared for the task and this resulted in extensive stress and generally negative attitudes towards the whole process. The participants mentioned that the task was given too early and they did not have enough skills or confidence to go out and start speaking Icelandic. One student said that:

As an idea, it is just wonderful, but it doesn't work as the teacher might hope for ... You are new to the country and you still don't really know it and you don't know the people. And you have to speak the language that you can't speak. And just to start speaking was a bit difficult. I was not ready for it. (Student in the Icelandic as a Second Language Practical Diploma Program)

The students' negative experiences of, and the failure in, this particular task may be explained by the substantial knowledge gap between students' existing communicative skills and the skills required to do the task. Research on communicative teaching methods further emphasized the importance of applying appropriate task-based assignments, which should not be far above the students' abilities and "should be challenging but not threatening" (Wesche \& Skehan, 2002, p. 217).

These experiences contradict the findings from Theodórsdóttir and Friðriksdóttir (2013), who studied students' experiences with the Íslenskuporpið task. The researchers reported that students had highly positive attitudes towards Íslenskuporpið and generally considered the task to be a success (Theodórsdóttir \& Friðriksdóttir, 2013). According to the interview guide in Theodórsdóttir and Friðriksdóttir's study, the students were specifically asked to describe the advantages of the task and its value. However, they were not specifically asked about the disadvantages or failures. The differences between students' experiences in Theodórsdóttir and Friðriksdóttir's (2013) study and those in the current study could be explained by the different focuses of the studies. The earlier study specifically focused on the Íslenskuporpið and particularly looked for positive experiences 
associated with it (Theodórsdóttir \& Friðriksdóttir, 2013). While the current study did not include any questions about the task concerned, the participants revealed their experiences when they were asked to comment on teaching methods applied by the teachers of Icelandic as a second language. Besides, the differences between these two studies could be explained in terms of the students' different learning styles, personalities or levels of language proficiency. Furthermore, the task was probably not adapted to new groups of students. Several theorists highlight that there is no single way of doing taskbased instruction; task-based assignments must be adapted to students' level of competence in the target language and other circumstances (R. Ellis, 2009; Richards, 2006; Swan, 2005). This creates challenges for teachers, because the same task can be highly relevant for one particular group of students but irrelevant for another group.

A participant who took the Icelandic language courses as elective courses revealed that one of the teachers in the BA program tried to combine interaction on social media and language teaching, and this teaching method worked for the students who experienced it. The participant described how engaged the teacher was in the educational process. "[The teacher] is really interested. [He/she] set up a Facebook group, and is desperate to talk to us all the time because [he/she] says that that is going to make us better". This element combines the dimensions of culturally responsive teaching (Gay, 2018; Nieto, 2010) and communicative language teaching (Gatbonton \& Segalowitz, 2005). The teacher cared about the students and their academic performance, used every opportunity to promote active interaction in Icelandic and helped to develop students' writing skills by communicating with them via a social media platform. The importance of creating a link between school and the outside world and using a variety of teaching approaches has previously been proved to be effective (Gay, 2018; Nieto, 2010; Ragnarsdóttir \& Blöndal, 2014). Two other participants who were enrolled in the BA Program confirmed that the above-mentioned approach to teaching is suitable for the Icelandic learning environment; it takes communicative language teaching to a different level, gives good results and motivates the students.

Group work is often described as one of the most significant elements of multicultural education because it triggers interactions between students and helps to create a positive atmosphere in the classroom (Banks \& Banks, 2010; De Vita, 2005; Gay, 2018; Popov et al., 2012). Additionally, it is suggested that group work helps to maintain students' motivation and interest in the second language learning process (Oroujlou \& Vahedi, 2011). Group work was one of the most discussed teaching methods during the interviews with the participants. Students' attitudes towards group work were very diverse. Some students really appreciated the group work and wished there were more group projects, while several students considered group work to be a waste of time.

A student in the BA program who had highly positive experiences of group work described it as an opportunity to share ideas with people from different cultures. "[Translated from Icelandic] When people come from different corners of the world and have different ideas, sometimes it is just enjoyable". Later in the interview, the participant explained that it was challenging to get used to each other at the start, as students involved in group work may have very different experiences and world views. 
Several other participants did not agree with the point of view that group work was a positive experience. They mentioned different reasons why group work was an unpleasant aspect that merely made the whole educational process more difficult. According to the participants, one of the main reasons for group work being experienced in a negative way was that the members of the group had different levels of language skills, which made advanced language users more active members of the group, while those whose level was relatively low became mute members and did not feel involved in the process. One participant who took the Icelandic language courses as elective courses commented that "[t]he group work is not chosen really carefully. Some of us had much more advanced knowledge and teachers just tend to communicate better with them". Another participant also brought up this issue:

[Translated from Icelandic] If someone speaks fluent Icelandic and I just come for example and say, "Good morning", this just doesn't work ... I think it is boring to do the group work ... It is best to divide students according to their level or according to their origin. (Student in the Icelandic as a Second Language BA Program)

While the participant's idea that it could be beneficial to divide students according to their origins might sound reasonable, several other participants concluded that working in a monocultural group might become an obstacle because they would start chatting in their native language and forget about the assignment and the purpose of the group work. Previous research suggests that group work is more productive when the members of the group have different backgrounds because they can share experiences and fill one another's knowledge gaps (De Vita, 2002, 2005). Furthermore, it is recommended that teachers assign group members rather than allowing students to choose group members themselves (De Vita, 2002, 2005). This would create more balanced groups.

Some participants did not fully understand the purpose of group work and were generally less satisfied with the process and the outcome. A participant shared his experience of the group work in one of the courses included in the BA program "[Translated from Icelandic] I think it is unfair to work in groups ... I don't know why group work [is assigned]. It doesn't show anything. We all got the same grade even though everybody agreed that I was the best". The participant did not reveal the name of the course, but he shared several details of the aforementioned group assignment. He highlighted that the teacher did not properly introduce the main goals of the group work up front. Furthermore, the participant was excessively focused on achievement and the final grade but not on the working process. It was not clear to him how the assignment was going to be assessed. The participant believed that the group members would be assessed individually, while in reality everyone was assessed as a group and received the same grade. Those are the reasons for the participant's dissatisfaction with the group work itself and with the grade when the assignment was finished. As pointed out by several different researchers in the field of higher education, a proper introduction to the purpose of group work assignments, making sure that every student understands the assessment methods before the actual group work begins, is crucially important for both students' experiences of the group work and the learning outcomes (Forehand, Leigh, Farrell, \& Spurlock, 2016; Hassanien, 2006; Sweeney et al., 2008). 
Apart from the communicative teaching methods, some of the courses included in the Icelandic as a Second Language BA Program placed a strong emphasis on the students' achievement in mastering the grammar of Icelandic. In the next section, the students' experiences of explicit grammar teaching methods will be presented and discussed.

\section{Explicit teaching of grammar: The emphasis on the students' achievement}

During the interviews, all of the participants who were enrolled in the BA program discussed their experiences of courses where explicit teaching of grammar was applied. They particularly shared their views on the courses Grammar and Syntax. Explicit teaching methods are considered useful by some theorists, especially when teachers are working on strengthening the students' knowledge of the target language and closing knowledge gaps by making the students aware of them (N. C. Ellis, 2015; R. Ellis, 2012). Despite the positive intention of applying such methods, the participants' experiences of the explicit teaching of grammar were mostly negative. The participants explained that the main reason for their dissatisfaction was that they did not feel involved in the learning process. The learning became a routine review of grammatical exercises and homework assignments. The emphasis on keeping the learning process within the frames of the syllabus and the predetermined number of assignments contributed to the students' negative experiences of the learning process:

They try to make sure that you follow the program. And at the end of the day, we ended up just doing the home tasks instead of being involved in the learning process. So, it was just ... I realized that I was a machine that produced homework. (Student in the Icelandic as a Second Language BA Program)

Later, the same student concluded that the workload in the Grammar and Syntax courses was very heavy. Two other participants shared this student's experience and mentioned that sometimes the amount of work was too much. They spent significantly more time studying for the courses where explicit teaching methods were applied than for the courses where implicit methods, such as communicative language teaching, were used. A participant, who had quit the program, concluded that one of the courses with the excessively heavy workload was probably a reason for quitting the studies:

[Translated from Icelandic] Probably I quit, because it was just too much for me. Yes, first the books that we had to study were not interesting to me and difficult ... And the home assignments ... I couldn't do everything. I was trying but no. (Student in the Icelandic as a Second Language BA Program)

The participants' negative attitudes towards the courses where explicit teaching methods of grammar are applied can potentially be explained using constructivist theory. The core elements in constructivist theory are learners' active participation and learner-centeredness (Cornelius-White, 2007; Schiller, 2009). The explicit teaching methods of grammar are intrinsically not learner-centered, and the participants have often described themselves as being passive recipients of knowledge in grammar courses. The findings 
indicated that the students enrolled in the BA program would appreciate being active participants in the learning process. They suggested that it could be more beneficial if the teachers could incorporate the teaching of grammar rules in communicative teaching through incidentally focusing on linguistic elements during the communicative activities in the classroom; that is, applied incidental focus-on-form approach. Another suggestion coming from the participants of the study was that they wished the teachers would invite them to discuss the syllabus at the beginning of every term, to allow them to evaluate the workload and probably choose some amount of the reading materials. This agrees with the suggestions made by culturally responsive pedagogy theorists, who emphasize the importance of constructive dialogue between teachers and students and, in some cases, allowing students to choose some of the learning materials (Gay, 2018; Villegas \& Lucas, 2002).

The majority of the participants indicated that they were less satisfied with the courses that based their assessment solely on the outcome of the final exam, which is a common practice in grammar courses. The participants would have liked the assessment to be diverse and more evenly divided throughout the academic semester. Previous research highlights the importance of applying different assessment methods throughout the learning process instead of relying on final exams (Montenegro \& Jankowski, 2017; Nicol \& Macfarlane-Dick, 2006; Slee, 2010). This is particularly relevant in culturally diverse classrooms, where students have different levels of knowledge and are used to different learning styles (Padilla \& Borsato, 2008; Slee, 2010). Those participants who came from countries outside the European Economic Area (EEA) experienced even more pressure because their residence permits depend on their academic performance at the university. A single failure in one exam could potentially have serious consequences for those students and, in some cases, might even result in a student having to leave the country (The Directorate of Immigration, n.d.-a, n.d.-b, n.d.-c).

Even though the study revealed several important problems relating to the teaching methods used in Icelandic language courses, the participants' overall experiences of the learning environment are positive. The participants hope to see improvement in the university and it would be appreciated if university administrators and teachers addressed the issues discussed in this paper.

\section{CONCLUSION}

The main goal of this study was to analyze the participants' perspectives on the teaching methods of Icelandic as a second language and their involvement in communication with the teachers. The findings presented here shed light on the individual participants' experiences of second-language education at the University of Iceland. Although the findings cannot be generalized beyond that, the study nevertheless gives some indication of challenges that other students might experience.

The findings indicate that the majority of the participants have positive attitudes towards the learning environment within the university. They highlight the fact that the majority of teachers are generally accessible and communication with them is easy. 
According to the participants, many teachers value the students' previous knowledge and care about their experiences and learning outcomes. Several participants in the study also shared negative experiences, which were usually caused by lack of communication between teachers and students. In a few cases, the participants reported that they had been refused educational support in the form of extra learning materials suited to the students' diverse proficiency levels. This contradicts the teaching practices based on multicultural education theory's important principles; that is, mutual respect, genuine concern for students and relevant educational support (e.g., Banks \& Banks, 2010; Gay, 2018).

When it comes to courses where implicit teaching methods are applied, the experiences of the participants were positive when teachers initiated class discussions and encouraged students to use Icelandic as much as possible during classroom activities. On the other hand, the participants' perspectives were less positive and, in some cases, negative when teachers applied a communicative task-based assignment called Íslenskuporpið, although task-based assignments, including Íslenskuporpið have been reported in the literature to have a positive influence on language learning. Some participants concluded that the task was not tailored to the students' proficiency level, applied too early in the learning process and could have worked better if the teacher had assigned the task in question later when the students' communication skills were more advanced.

The participants' attitudes to group work were diverse. Some participants valued group work and saw it as an opportunity to exchange knowledge and learn from one another. On the other hand, several participants saw the group work as a challenge. While the theorists recommend group work as a teaching method, especially in the field of multicultural education (Banks \& Banks, 2010), different studies emphasize the importance of properly introducing the goals of the group work and explaining how the working process should be carried out (Forehand et al., 2016; Hassanien, 2006; Sweeney et al., 2008). Teachers' failure to introduce the benefits of group work together with insufficient explanations of assessment methods could result in students' negative experiences, such as those described in detail by one of the participants in the current study.

The participants' main concerns were mostly related to courses where explicit teaching methods, such as grammar teaching, were applied. The participants felt those courses were mere knowledge transmission where the students were passive recipients. Furthermore, the participants had negative attitudes towards the assessment being solely based on final exams and preferred diverse assessment methods and assessment evenly divided throughout the academic semester. Multicultural education theory and constructivist theory support the participants' views and highlight the importance of implementing learner-centered approaches to teaching and applying diverse assessment methods (Banks \& Banks, 2010; Cornelius-White, 2007; Padilla \& Borsato, 2008; Schiller, 2009; Slee, 2010).

The presented research indicates the participants' overall satisfaction with the Icelandic language courses. According to the participants, university staff members are criticism-tolerant and genuinely willing to work on resolving issues and creating an empowering learning environment. Apart from the main goal of presenting and analyzing students' 
perspectives regarding the learning environment and the teaching methods, the secondary aim of the study is to motivate further research on adult students' experiences of second language learning in Iceland, because the volume of research and knowledge within this area is still relatively low.

\section{REFERENCES}

Banks, J. A., \& Banks, C. A. M. (2010). Multicultural education: Issues and perspectives (7th ed.). Hoboken: Wiley.

Birenbaum, M. (2003). New insights into learning and teaching and their implications for assessment. In M. Segers, F. Dochy, \& E. Cascallar (Eds.), Optimising new modes of assessment: In search of qualities and standards (pp. 13-36). Dordrecht: Kluwer.

Braun, V., \& Clarke, V. (2013). Successful qualitative research: A practical guide for beginners. London: SAGE.

Brinkmann, S., \& Kvale, S. (2015). InterViews: Learning the craft of qualitative research interviewing (3rd ed.). Thousand Oaks: SAGE.

Cornelius-White, J. (2007). Learner-centered teacher-student relationships are effective: A meta-analysis. Review of Educational Research, 77(1), 113-143. https://doi. org/10.3102/003465430298563

Creswell, J. W. (2008). Educational research: Planning, conducting, and evaluating quantitative and qualitative research (3rd ed.). Upper Saddle River: Pearson.

De Vita, G. (2002). Does assessed multicultural group work really pull UK students' average down? Assessment \& Evaluation in Higher Education, 27(2), 153-161. https://doi. org/10.1080/02602930220128724

De Vita, G. (2005). Fostering intercultural learning through multicultural group work. In J. Carroll \& J. Ryan (Eds.), Teaching international students: Improving learning for all (pp. 75-83). New York: Routledge.

The Directorate of Immigration. (n.d.-a). Refusal of residence permit. Retrieved from https://utl.is/index.php/en/refusal-of-residence-permit

The Directorate of Immigration. (n.d.-b). Renewal and student enrollment. Retrieved from https://utl.is/index.php/en/residence-permits-for-students/renewal-and-studentenrollment

The Directorate of Immigration. (n.d.-c). Residence permits for students. Retrieved from https://utl.is/index.php/en/residence-permits-for-students

Ellis, N. C. (2015). Implicit and explicit language learning: Their dynamic interface and complexity. In P. Rebuschat (Ed.), Implicit and explicit learning of languages (pp. 3-24). Amsterdam: John Benjamins.

Ellis, R. (2009). Task-based language teaching: Sorting out the misunderstandings. International Journal of Applied Linguistics, 19(3), 221-246. https://doi.org/10.1111/ j.1473-4192.2009.00231.x

Ellis, R. (2012). Language teaching research and language pedagogy. Hoboken: Wiley-Blackwell.

Erisman, W., \& Looney, S. (2007). Opening the door to the American dream: Increasing higher education access and success for immigrants. Washington: Institute for Higher Education Policy. 
Flick, U. (2009). An introduction to qualitative research (4th ed.). London: SAGE.

Forehand, J. W., Leigh, K. H., Farrell, R. G., \& Spurlock, A. Y. (2016). Social dynamics in group work. Teaching and Learning in Nursing, 11(2), 62-66. https://doi.org/10.1016/j. teln.2015.12.007

Gatbonton, E., \& Segalowitz, N. (2005). Rethinking communicative language teaching: A focus on access to fluency. Canadian Modern Language Review, 61(3), 325-353. https://doi.org/10.3138/cmlr.61.3.325

Gay, G. (2018). Culturally responsive teaching: Theory, research, and practice (3rd ed.). New York: Teachers College Press.

Harmer, J. (1987). Teaching and learning grammar. New York: Longman.

Hassanien, A. (2006). Student experience of group work and group assessment in higher education. Journal of Teaching in Travel \& Tourism, 6(1), 17-39. https://doi. org/10.1300/J172v06n01_02

Hjartardóttir, P. B. (2000). Íslenskukennsla útlendinga við Háskóla Íslands [Icelandic language teaching for foreigners at the University of Iceland]. Málfregnir, 10(19), 29-33.

Karge, B. D., Phillips, K. M., Jessee, T., \& McCabe, M. (2011). Effective strategies for engaging adult learners. Journal of College Teaching \& Learning, 8(12), 53-56. https://doi. org/10.19030/tlc.v8i12.6621

Krashen, S. (1985). The input hypothesis: Issues and implications. London: Longman.

Lado, R. (1964). Language teaching: A scientific approach. New York: McGraw-Hill.

Loewen, S. (2005). Incidental focus on form and second language learning. Studies in Second Language Acquisition, 27(3), 361-386. https://doi.org/10.1017/S02722631 05050163

Long, M. H. (2011). Methodological principles for language teaching. In M. H. Long \& C. J. Doughty (Eds.), The handbook of language teaching (pp. 373-394). Chichester: Wiley-Blackwell.

Montenegro, E., \& Jankowski, N. A. (2017). Equity and assessment: Moving towards culturally responsive assessment. Urbana: University of Illinois and Indiana University, National Institute for Learning Outcomes Assessment (NILOA).

Nicol, D. J., \& Macfarlane-Dick, D. (2006). Formative assessment and self-regulated learning: A model and seven principles of good feedback practice. Studies in Higher Education, 31(2), 199-218. https://doi.org/10.1080/03075070600572090

Nieto, S. (2010). The light in their eyes: Creating multicultural learning communities (10th anniversary ed.). New York: Teachers College Press.

Norris, J. M. (2011). Task-based teaching and testing. In M. H. Long \& C. Doughty (Eds.), The handbook of language teaching (pp. 578-594). Chichester: Wiley-Blackwell.

Norton, B., \& Toohey, K. (2011). Identity, language learning, and social change. Language Teaching, 44(4), 412-446. https://doi.org/10.1017/S0261444811000309

Oroujlou, N., \& Vahedi, M. (2011). Motivation, attitude, and language learning. Procedia - Social and Behavioral Sciences, 29, 994-1000. https://doi.org/10.1016/j.sbspro.2011.11.333 
Padilla, A. M., \& Borsato, G. N. (2008). Issues in culturally appropriate psychoeducational assessment. In L. A. Suzuki \& J. G. Ponterotto (Eds.), Handbook of multicultural assessment: Clinical, psychological, and educational applications (3rd ed., pp. 5-21). San Francisco: Jossey-Bass.

Pedersen, M. S. (2007). Tjáskiptaverkefni: Árangursrík leið í tungumálakennslu [Taskbased assignments: Effective way in language teaching]. In Auður Hauksdóttir \& Birna Arnbjörnsdóttir (Eds.), Mál málanna: Um nám og kennslu erlendra tungumála [Language and languages: About learning and teaching foreign languages] (pp. 201-233). Reykjavík: Stofnun Vigdísar Finnbogadóttur í erlendum tungumálum.

Popov, V., Brinkman, D., Biemans, H. J. A., Mulder, M., Kuznetsov, A., \& Noroozi, O. (2012). Multicultural student group work in higher education: An explorative case study on challenges as perceived by students. International Journal of Intercultural Relations, 36(2), 302-317. https://doi.org/10.1016/j.ijintrel.2011.09.004

Ragnarsdóttir, H., \& Blöndal, H. (2014). Fjölmenningarlegt námssamfélag: Reynsla nemenda af alpjóđlegu námi í menntunarfræđi við Háskóla Íslands [Multicultural learning community: The experiences of students in the International Studies in Education programme at the University of Iceland]. Uppeldi og menntun, 23(1), 27-45.

Richards, J. C. (2006). Communicative language teaching today. New York: Cambridge University Press.

Schiller, S. Z. (2009). Practicing learner-centered teaching: Pedagogical design and assessment of a Second Life project. Journal of Information Systems Education, 20(3), 369-381.

Sinacore, A. L., \& Lerner, S. (2013). The cultural and educational transitioning of first generation immigrant undergraduate students in Quebec, Canada. International Journal for Educational and Vocational Guidance, 13(1), 67-85. https://doi.org/10.1007/ s10775-013-9238-y

Slee, J. (2010). A systemic approach to culturally responsive assessment practices and evaluation. Higher Education Quarterly, 64(3), 246-260. https://doi.org/10.1111/ j.1468-2273.2010.00464.x

Statistics Iceland. (2016). Immigrants and persons with foreign background 2016. Retrieved from http://statice.is/publications/news-archive/population/immigrantsand-persons-with-foreign-background-2016/

Swain, M. (1993). The output hypothesis: Just speaking and writing aren't enough. Canadian Modern Language Review, 50(1), 158-164. https://doi.org/10.3138/cmlr.50.1.158

Swain, M. (2005). The output hypothesis: Theory and research. In E. Hinkel (Ed.), Handbook of research in second language teaching and learning (pp. 471-483). Mahwah: Lawrence Erlbaum.

Swain, M., \& Lapkin, S. (1995). Problems in output and the cognitive processes they generate: A step towards second language learning. Applied Linguistics, 16(3), 371-391. https://doi.org/10.1093/applin/16.3.371

Swan, M. (2005). Legislation by hypothesis: The case of task-based instruction. Applied Linguistics, 26(3), 376-401. https://doi.org/10.1093/applin/ami013 
Sweeney, A., Weaven, S., \& Herington, C. (2008). Multicultural influences on group learning: A qualitative higher education study. Assessment \& Evaluation in Higher Education, 33(2), 119-132. https://doi.org/10.1080/02602930601125665

Theodórsdóttir, G., \& Friðriksdóttir, K. (2013). Íslenskuporpið: Leið til pátttöku í daglegum samskiptum á íslensku [The Icelandic village: Participation in everyday-life interaction in Icelandic]. Milli mála, 5, 13-44.

University of Iceland. (n.d.-a). Brautskráning [Graduation]. Retrieved from https://www. hi.is/nam/brautskraning

University of Iceland. (n.d.-b). Icelandic as a second language. Retrieved from https:// english.hi.is/school_of_humanities_faculty_of_icelandic_and_comparative_cultural_studies/icelandic_as_a_second

University of Iceland. (n.d.-c). Nemendur [Students]. Retrieved from https://www.hi.is/ kynningarefni/nemendur

University of Iceland. (2017). Icelandic as a second language: Programme structure. Retrieved from https://ugla.hi.is/kennsluskra/index.php?tab=nam\&chapter=namsleid \&id=054050_20176\&kennsluar $=2017$

Villegas, A. M., \& Lucas, T. (2002). Preparing culturally responsive teachers: Rethinking the curriculum. Journal of Teacher Education, 53(1), 20-32. https://doi.org/10.1177/ 0022487102053001003

Wagner, J. (2004). The classroom and beyond. The Modern Language Journal, 88(4), 612-616.

Wesche, M. B., \& Skehan, P. (2002). Communicative, task-based, and content-based language instruction. In R. B. Kaplan (Ed.), The Oxford handbook of applied linguistics (pp. 207-228). New York: Oxford University Press.

The article was received 7th November 2019 and was accepted 4th March 2020

\section{ABOUT THE AUTHORS}

Artëm Ingmar Benediktsson (artem@hi.is) is a Ph.D. candidate at the School of Education, University of Iceland. He completed a B.S. degree in geology from the People's Friendship University of Russia in 2008, a B.A. degree in Danish from the University of Iceland in 2013 and an M.A. degree in Nordic studies from the University of Iceland in 2015. Artëm embarked on his Ph.D. in 2016. His research focuses on immigrant students' experiences of learning environments and teaching methods used in Icelandic universities.

Hanna Ragnarsdottir (hannar@hi.is) is a professor at the School of Education, University of Iceland. She completed a B.A. degree in anthropology and history from the University of Iceland in 1984, an M.Sc. degree in anthropology from the London School of Economics and Political Science in 1986, and a Dr.philos. in education from the University of Oslo in 2007. Her research has mainly focused on immigrants and refugees (children, adults, and families) in Icelandic society and schools, multicultural education, and school reform. 